\title{
DEVELOPMENT OF ANTIVIRAL THERAPEUTICS COMBATING COXSACKIEVIRUS TYPE B3 INFECTION
}

\author{
A.S. Volobueva ${ }^{a}$, V.V. Zarubaev ${ }^{a}$, K.S. Lantseva ${ }^{b}$ \\ ${ }^{a}$ St. Petersburg Pasteur Institute, St. Petersburg, Russian Federation \\ ${ }^{b}$ St.Petersburg State University, St. Petersburg, Russian Federation
}

\begin{abstract}
Enteroviruses comprise highly diverse group of single-stranded positive RNA viruses belonging to Enterovirus genus, Picornaviridae family. They are the most prevalent viruses worldwide highlighted by high resistance to environmental cues. Enteroviruses normally cause seasonal self-limiting infections, but also known as causative infectious agents of encephalitis, myocarditis, poliomyelitis, acute heart failure and sepsis. Enterovirus genetic plasticity contributes to widespread epidemics and sporadic outbreaks (e. g., outbreaks of Enterovirus D68 and Enterovirus 71). Type B Coxsackieviruses of Enterovirus B species is one of commonly identified infectious agents associated predominantly with mild upper respiratory and gastrointestinal illnesses. Nevertheless, Coxsackieviruses B3 infection can result in severe myocarditis leading ultimately to heart failure. The pathogenesis of Coxsackievirus B3-induced myocarditis is well known being mediated by both direct damage due to viral proteases and indirectly via secondary host immune responses. Despite success in preventive vaccination of some enterovirus infections that allowed to control some of them direct antiviral agents for treatment of enteroviral infection particularly Coxsackieviruses B3 myocardial infection are still in demand. In addition, no ongoing clinical trials for therapy or prevention of Coxsackieviruses B3 infection are available. Current treatment strategies are mainly aimed to stabilize patient condition and relieve discomfort condition. It seems that relatively small market for anti-enteroviral drugs prevents pharma industry from developing new drugs. The Coxsackieviruses B3 lifecycle have been extensively studied and potential targets for drug design have been identified. The aim of our review was to describe current state in the field of antiviral drug design combating Coxsackieviruses B3 infection emphasizing direct-acting antivirals, albeit paying some attention to host factor-targeting inhibitors (including compounds from medicinal plant extracts) as well. The following categories of direct Coxsackieviruses B3 inhibitors are discussed in detail: capsid binders (pleconaril and its derivatives), viral 3C protease inhibitors (rupintrivir and its analogs), drugs targeting viral replication (both nucleoside analogs and non-nucleoside inhibitors). Results of drug repurposing screens for amiloride, benzerazide, dibucaine and fluoxetine are also discussed.
\end{abstract}

Key words: Enteroviruses, Coxsackievirus, infection, myocarditis, antivirals, drug development, inhibitor.

\section{РАЗРАБОТКА ПРОТИВОВИРУСНЫХ ПРЕПАРАТОВ ДЛЯ ТЕРАПИИ ИНФЕКЦИИ КОКСАКИВИРУСА ВЗ} Волобуева А.С. ${ }^{1}$, Зарубаев В.В. ${ }^{1}$, Ланцева К.С. ${ }^{2}$

${ }^{I}$ ФБУН НИИ эпидемиологии и микробиологии им. Пастера, Санкт-Петербург, Россия

${ }^{2}$ Санкт-Петербургский государственный университет, Санкт-Петербург, Россия

Резюме. Энтеровирусы представляют собой разнообразную группу безоболочечных одноцепочечных положительных РНК-вирусов, принадлежащих к роду энтеровирусов семейства Picornaviridae. Они являются

\section{Адрес для переписки:}

Волобуева Александрина Сергеевна

197101, Россия, Санкт-Петербург, ул. Мира, 14,

ФБУН НИИ эпидемиологии и микробиологии имени Пастера.

Тел.: 8 (921) 365-05-48.

E-mail: sasha-khrupina@mail.ru

\section{Для цитирования:}

Волобуева А.С., Зарубаев В.В., Ланцева К.С. Разработка

противовирусных препаратов для терапии инфекции

коксакивируса В3 // Инфекция и иммунитет. 2021. Т. 11, № 1. С. 57-67. doi: 10.15789/2220-7619-DOA-1273

\section{Contacts:}

Aleksandrina S. Volobueva

197101, Russian Federation, St. Petersburg, Mira str., 14,

St. Petersburg Pasteur Institute.

Phone: +7 (921) 365-05-48.

E-mail: sasha-khrupina@mail.ru

Citation:

Volobueva A.S., Zarubaev V.V., Lantseva K.S. Development of antiviral therapeutics combating coxsackievirus type B3 infection // Russian Journal of Infection and Immunity = Infektsiya i immunitet, 2021, vol. 11, no. 1, pp. 57-67. doi: 10.15789/2220-7619-DOA-1273 
наиболее распространенными вирусами в мире и отличаются высокой устойчивостью к факторам внешней среды. Энтеровирусы вызывают сезонные инфекции, а также являются возбудителями энцефалита, миокардита, полиомиелита, острой сердечной недостаточности и сепсиса. Генетическая пластичность энтеровирусов способствует возникновению эпидемий и спорадических вспышек (например, вспышки инфекции энтеровируса D68 или энтеровируса 71). Вирусы Коксаки типа В, принадлежащие к виду энтеровирус В, вызывают преимущественно легкие заболевания верхних дыхательных путей и желудочно-кишечного тракта, но инфекция вируса Коксаки В3 также ассоциирована с развитием миокардита, который, в свою очередь, может привести к сердечной недостаточности. Патогенез миокардита, индуцированного вирусом Коксаки В3, хорошо изучен, он опосредован как прямым повреждением под действием протеаз вируса, так и косвенным повреждением вследствие иммунного ответа организма. Несмотря на успех в области вакцинопрофилактики ряда энтеровирусных инфекций, благодаря которому некоторые из них были взяты под контроль, сохраняется потребность в противовирусных препаратах, активных в отношении энтеровирусов. На сегодняшний день отсутствуют зарегистрированные противовирусные препараты прямого действия для терапии большинства энтеровирусных инфекций, в частности инфекции вируса Коксаки В3. Также не проводятся клинические испытания в области лечения или профилактики инфекции вируса Коксаки В3. Доступные стратегии лечения направлены на стабилизацию состояния пациента и снятию дискомфорта. Вероятно, относительно небольшой рынок препаратов против энтеровирусных инфекций является непривлекательным для фармацевтических компаний. Жизненный цикл вируса Коксаки В3 был тщательно изучен, и известны потенциальные привлекательные мишени для разработки противовирусных препаратов. Целью настоящей работы является обзор текущего состояния области разработки противовирусных препаратов против инфекции вируса Коксаки В3, особое внимание уделено разработке противовирусных препаратов прямого действия. Также упомянуты ингибиторы, нацеленные на клеточные факторы развития инфекции (включая соединения экстрактов лекарственных растений). Подробно рассмотрены следующие категории прямых ингибиторов вируса Коксаки В3: капсид-связывающие агенты (плеконарил и его производные), ингибиторы протеазы 3С (рупинтривир и его аналоги), ингибиторы репликации (как аналоги нуклеозидов, так и ненуклеозидные ингибиторы). Кроме того, в обзор включены результаты исследований перепрофилирования зарегистрированных лекарственных препаратов (амилорида, бензеразида, дибукаина и флуоксетина).

Ключевые слова: энтеровирусы, коксакивирус, инфекция, миокардит, противовирусные средства, разработка лекарств, ингибитор.

\section{Introduction}

Enteroviruses are diverse group of small (30-32 nm size) icosahedral non-enveloped viruses with single-stranded non-segmented positive RNA with a poly(A) tail genome belonging to Picornaviridae family (International Committee on Taxonomy of Viruses). They are able to survive harsh environment and can cause both self-limiting infections, as well as polio, hand, foot and mouth disease and heart and central nervous system diseases. Currently genus Enterovirus encompasses 15 species: Enterovirus A-L and Rhinovirus A-C (picornavirus. com). Coxsackieviruses type B (CVB) are members of Enterovirus B species and include six serotypes (CVB1-6). CVB are lytic viruses but persistent infection responsible for chronic inflammation within target organs can be established. CVB3 often leads to mild upper respiratory and gastrointestinal illnesses, but it can also cause myocarditis. The pathogenesis of CVB3 induced myocarditis depends on both direct injury mediated by viral proteinases and indirect damage secondary to host immune responses. Myocarditis can resolve spontaneously or can progress to stable dilated cardiomyopathy (DCM). DCM patients develop heart pump weakening, heart valve problems, blood clots, and arrhythmias leading to heart and secondary organ failures [5]. In Russian Federation CVB3 infection is also quite common among adults and children. According to the survey held in different regions in Russian Federation (2006-2015), the percentage of CVB3 in samples from patients hospitalized with enteroviral infection was rather high $-26 \%$ [1]. Despite numerous efforts, there are no direct antiviral medications approved by FDA for the treatment of enterovirus infections to date. Neither are there ongoing clinical trials in the field of CVB infection treatment or prophylaxis. Therefore, the development of novel broad-range antiviral drugs against enteroviruses including CVB3 is highly desirable.

The aim of the present review is to describe the current state of direct antiviral drug development active against Coxsakievirus type B3 infection.

\section{CVB lifecycle}

The structure of Coxsackievirus and its life cycle have been extensively studied [28]. $30 \mathrm{~nm}$ Coxsackievirus capsids are composed of 60 copies of biological protomers made of four capsid proteins: VP1, VP2, VP3, and VP4 arranged in icosahedral lattice. In mature virions, myristoylated VP4 and the N-terminus of VP1 are located on the 
internal surface of the capsid shell. Its outer surface is characterized by depression around the icosahedral fivefold axes of symmetry (the "canyon"), and depression at the twofold axes of symmetry, which are the primary and secondary receptor-binding sites on Coxsackievirus, respectively. Underneath the "canyon", there is a hydrophobic pocket, occupied by a pocket factor, modeled as a C16 fatty acid. Expulsion of the "pocket factor" upon virus binding to its receptor is a prelude to a series of uncoating events, leading to release of viral genome into the cytosol [7]. Coxsackievirus RNA is uncapped and contains one single open reading frame (ORF) flanked by a highly structured $5^{\prime}$ non-translated region (NTR) and a polyadenylated 3'NTR. A small virion protein genome-linked protein $(\mathrm{VPg})$ is covalently linked to the $5^{\prime}$ end and a poly(A) tail at the $3^{\prime}$ end. $5^{\prime}$ NTR contains sequences important for translation and replications [4]. Besides a cardiovirulent determinant has been identified in domain II of the $5^{\prime}$ NTR [10]. VPg is used as a primer for positivestrand and negative-strand RNA synthesis. ORF is translated into a single long polypeptide containing the $\mathrm{P} 1, \mathrm{P} 2$ and $\mathrm{P} 3$ regions. The $\mathrm{P} 1$ region codes for capsid proteins (structural proteins) while nonstructural proteins are expressed from P2 and P3 regions [14]. Though the nonstructural proteins are mainly involved in synthesizing new viral RNA, they can also interfere with cellular processes via shutting off cellular translation as well as inhibiting the induction of an immune response.

The typical infectious cycle of enteroviruses is about $5-10 \mathrm{~h}$. Coxsackievirus enters a target cell upon binding the coxsackie and adenovirus receptor (CAR) as the major receptor and decay accelerating factor (DAF) as a co-receptor. In polarized epithelial cells, CAR as a component of the tight junction is inaccessible to virus approaching from the apical surface. Therefore, Coxsackievirus binds to DAF on the apical cell surface, it activates Abl kinase, triggering Rac-dependent actin rearrangements that permit virus movement to the tight junction and binding to CAR [9]. On CAR-poor cells CVB3 is able to bind additional cell surface ligands, for example, CVB3 $\mathrm{PD}$ variant use $\mathrm{N}$ - and 6-O-sulfated heparan sulfates to enter CAR-negative $\mathrm{CHO}-\mathrm{K} 1$ cells. In this case, the timing of cell penetration is longer, but longevity of a viral life cycle is independent of the utilized receptor [45].

After penetrating the cell, the virus is uncoated and the positive sense RNA is translated in cap independent manner. The 5'NTR contains cis-acting internal ribosome entry site (IRES) that recruits ribosomes directly to a downstream AUG codon [4]. Upon translation, the viral polyprotein is cleaved into precursors and then mature structural proteins (VP 1-4) and non-structural proteins (2A-C, 3A-D) by the virally encoded proteases $2 \mathrm{~A}$ and $3 \mathrm{C}$ [14]. Both the nonstructural proteins and their precursors
(3AB, 3CD) form the membrane-associated replication complex. Although $3 \mathrm{C}$ protease is responsible for the majority of the newly synthesized viral polyprotein cleavage, $2 \mathrm{~A}$ protein performs the primary cleavage event separating the structural protein precursor (P1 segment) from the nonstructural one (P2 segment). Both proteases have chymotrypsin-like structure with a cysteine nucleophile. 2A protease catalyzes the single cleavage of the viral polyprotein at a tyrosine-glycine pair between the C-terminus and $\mathrm{N}$-terminus of VP1. 3C protease targets distinct glutamine-glycine residues with a preferred consensus cleavage motif of AXXQ $\downarrow$ GPXX (X denotes any amino acid and the arrow represents the scissile bond (peptide bond hydrolyzed by the protease) between the $\mathrm{P} 1^{\prime}$ to $\mathrm{P} 4$ ' and $\mathrm{P} 1$ to $\mathrm{P} 4$ amino acid residues of the substrate, respectively). In addition, active picornavirus proteases have alternative functions, including shutting off the host mRNA translation and protein synthesis and induction of apoptosis by the cleavage of host cell proteins, such as translation initiation factor $\mathrm{G}$, stimulation factor 64, eIF4GI, a component of cap-binding complex eIF4F [17]. The precise regulation of these proteases, their activities, and their overlapping and unique functions remains to be fully understood.

Coxsackievirus replication takes place in the cytoplasm on the outer surface of membranous vesicles, cholesterol trafficking from cell membrane to replication organelles is thus necessary for viral propagation. Protein 2B tetramer acts as viroporine and increases the permeability of membranous structures, disturbs $\mathrm{Ca}^{2+}$ balance, regulates apoptosis and autophagy in host cell. It integrates into the membranes of Golgi apparatus and the endoplasmic reticulum (ER), makes a pore and releases calcium from them to the cytoplasm. The disruption of calcium homeostasis leads to endoplasmic reticulum stress and production of vesicles from Golgi apparatus membrane. These vesicles are associated with virus replication complexes and display autophagosomal markers [31]. Endoplasmic reticulum stress is associated with the progression of viral myocarditis and cardiac tissue fibrosis [6]. 3A protein also targets the Golgi apparatus and inhibits anterograde trafficking, thus downregulating distribution of major histocompatibility complex (MHC) class I molecules. It makes infected cells invisible for $\mathrm{CD}^{+} \mathrm{T}$-cell immune response [8]. The role of nonstructural $2 \mathrm{C}$ protein in enteroviral lifecycle is complex and still not fully understood. 2C protein has RNA-binding, nucleotide binding and ATPase activities It participates in various processes including RNA binding and replication, membrane anchoring and rearrangement, encapsidation and viral morphogenesis, and suppression of nuclear factor kappa B activation. Recently, it was discovered that $2 \mathrm{C}$ combines functions of ATP-dependent RNA helicase (it unwinds RNA helices 3'-to-5) and ATPindependent RNA chaperone, that destabilizes heli- 
ces bidirectionally and facilitates strand annealing and complex RNA structure formation [43].

It is known, that enteroviruses $3 \mathrm{AB}$ precursor protein localizes the viral replication complex to the surface of membranous vesicles and acts as a cofactor to stimulate the activity of $3 \mathrm{D}$ polymerase (3Dpol). Genome replication of CVB3 has been described in details [11]. It is catalyzed by the viral RNAdependent RNA polymerase in association with a number of viral and host proteins. The first step in viral replication involves the synthesis of a negative complementary strand [(-) RNA], which serves as a template for the production of positive RNAstrands [(+) RNA]. The synthesis of both RNA strands is initiated by $3 \mathrm{~B}(\mathrm{VPg})$ uridylylation: the attachment of two UMP nucleotides to a tyrosine residue of VPg. VPgpUpU serves as the primer for 3Dpol to initiate synthesis of both $(-)$ and (+) RNA strands. $\mathrm{VPg}$ requires a template. In the case of $(+)$ strand synthesis, an internal stem-loop in the genomic RNA strand (cis-acting replication element, CRE) is used as a template, then VPg-pUpU is translocated to the $3^{\prime}$ end of the complementary strand and is elongated into a full-length genomic strand. The complementary strand synthesis can be templated by CRE and the poly(A) tail of the genomic strand.

CVB3 virion morphogenesis is poorly understood, but it is known that glutathione is an essential stabilizing cofactor during the transition of protomeric particles into pentameric particles and, for example, direct binding of inhibitor TP219 to glutathione interferes with virus morphogenesis without affecting viral RNA replication [38]. 2C protein also can participate in viral RNA encapsidation, because 2C binds both RNA and virion protein VP3 [25]. After assembly, non enveloped virions are released from the cell mainly through cell lysis. Recently, it was shown, that CVB3 harnesses secretory autophagy: its virions are released from cells inside extracellular microvesicles, which hide virions from host neutralizing antibodies [33]. During the onset of infection, autophagy may help cell clear the virus, whereas later autophagy may be used for viral replication and transmission.

\section{Current therapeutic approaches for CVB3 infection}

Depending on the target, antiviral drugs can be classified into direct-acting antivirals and host factortargeting inhibitors. Examples of host factor-targeting drugs with proved activity against CVB3 are itraconazole, umifenovir (Arbidol) [37, 35]. Various hosttargeting drugs are of medicinal plant origin, for instance, $\alpha$-bromo-4-chlorocinnamaldehyde (BCC), derived from cinnamaldehyde, the major component of the essential oil of cinnamon bark [46]. BCC inhibited CVB3 replication in vitro and reduced CVB3 induced heart damage in infected mice possibly by sup- pression of TLR4 and/or NfkB activation. Oroxylin, an O-methylated flavone, isolated from aerial parts of Scutellaria baicalensis, demonstrated cytoprotective effect against CVB3 in vitro and mitigated pancreatic lesions in vivo in mice model of CVB3 pancreatitis. It was shown, that oroxylin increased phosphorylation of eIF2 $\alpha$, which takes part in ER stress response [21]. Manassantin B (ManB), a lignan isolated from Saururus sp., displayed significant antiviral activity against group B coxsackieviruses in vitro during early steps of infection [36]. In mouse model of pancreatic CVB3 infection ManB treatment prevented body weight loss and decreased proinflammatory cytokines levels. Mechanistic studies suggested that ManB antiviral activity was associated with increased mitochondrial ROS production and activation of type I IFN signaling through cGAS/STING/TBK-1/IRF3 pathway. Unfortunately, for many tested plant extracts or derivatives the mechanisms of action were not determined or even studied. In this review, we will further focus on discovery of molecules having a defined direct viral target in CVB3 lifecycle and describe progress made in the field of direct-acting drugs development.

\section{Direct CVB3 antivirals}

\section{Inhibitors of viral binding, internalization or uncoating}

The conserved capsid structure of enteroviruses provides the basis for rational design of capsid binders with broad antiviral activity. Several molecules have been identified, that selectively inhibit the interaction of CVB with its receptor. Most capsid binders discovered execute their antiviral activity via interaction with the hydrophobic pocket at the floor of the canyon. The capsid binders stabilize the virion by pushing the bottom of the canyon upwards to prevent capsid conformational change necessary for virus uncoating. It is possible that drug integration with capsid during virion assembly additionally contributes to the antiviral activity. Capsid binders are the best studied inhibitors, but their obvious disadvantage is the rapid selection for drug-resistant strains.

In the 1980s a series of "WIN-compounds" were produced, among them WIN 63843 (pleconaril, 3-[3,5-dimethyl-4-[3-(3-methyl-1,2-oxazol-5-yl) propoxy]phenyl]-5-(trifluoromethyl)-1,2,4-oxadiazole, Fig. 1) was demonstrated to have a broad activity against enteroviruses including CVB [32].

As mentioned above, one of the main disadvantages of pleconaril is the emerging of resistance. Mutation, conferring high-level resistance to pleconaril, are located in amino acid residues forming the hydrophobic pocket (I1092L or I1092M) hence directly interfering with the binding of capsid inhibitors, as well as outside the pocket (I1207K and I1207R substitutions). Originally I1092L or I1092M CVB3 variants were described to be significantly less stable than wild type virus and have attenuated viru- 
lence with both reduced mortality and delayed time to death in mice, but later highly mouse-pathogenic, pleconaril-resistant I1092L or I1092M CVB3 have been isolated [13]. Unfortunately, FDA panel voted to reject pleconaril, because the panel remained unconvinced about the drug's safety profile due to the side effects of pleconaril treatment: it induced cytochrome P-450 3A (CYP 3A) enzymes, which metabolize a variety of drugs. CYP $3 \mathrm{~A}$ induction is an undesirable drug interaction, affecting the efficacy of co-administered drugs, rather than safety. It was shown that administration of pleconaril may decrease plasma concentrations of CYP3A substrates, including some contraceptive steroids [16].

Since its discovery, various pleconaril derivatives have been designed and checked for anti-CVB activity. It is known, that methyl groups in capsid binder could be important for binding via hydrophobic interactions with the Ile1092 of pleconaril-sensitive CVB3, as well as they may sterically prevent capsid binders from proper positioning into the hydrophobic pocket of pleconaril-resistant CVB3 variants (Leu1092 or Met1092). A 3-bromine derivative of pleconaril (5-(trifluoromethyl)-3-[3-bromo-4-[[3-(3-methyl5-isoxazol) propyl]-oxylphenyl]-1,2,4-oxadiazole, Fig. 2) was obtained, that demonstrated high-level inhibition of pleconaril-sensitive CVB3 in vitro [34]. Importantly, the study results highlighted that both volume and lipophilicity of a compound are important determinants of anti-CVB3 activity.

Later different classes of capsid binders have been identified that demonstrated high CVB3 infection inhibition either in vitro or in vivo, and low cytotoxicity.

Among chemical library of pyrazolopyrimidines the lead compound, 4-trifluoromethylphenyl)amino6-phenylpyrazolo[3,4-d]pyrimidine-4-amine, OBR5-340 (Fig. 3), strongly inhibited the cytopathic effect of both pleconaril-resistant and susceptible CVB3 strains without induction of CYP3A (undesirable drug interaction) like pleconaril. Due to its favorable pharmacokinetic, toxicological and pharmacodynamics profile in mice, it was considered as highly promising drug candidate, but currently there are no information whether it will go into clinical trials [27].

Recently novel class of capsid binders having alternative binding mode were designed and tested in vitro. 4-dimethylamino benzoic acid (4EDMAB, Fig. 4) and it derivatives demonstrated antiviral activity against CVB1-6 [26]. It acts via a mechanism different from that of the "classical" capsid binders. Thermostability assay proved that $4 \mathrm{EDMAB}$, like pleconaril, binds directly to the capsid and targets VP1, but results of molecular modeling suggested that 4EDMAB interacts with a small cavity located outside the range of the canyon and outside the hydrophobic pocket. Combinational study with pleconaril showed a synergistic antiviral effect, which further indicates a distinct mechanism of action for 4EDMAB.

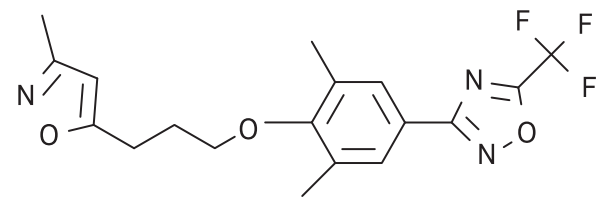

Figure 1. Pleconaril structure<smiles>CC(=N)/C=C(\O)CCCOc1ccc(-c2noc(C(F)(F)F)n2)cc1Br</smiles>

Figure 2. Potent 3 bromide pleconaril derivative<smiles>Cc1nc(-c2ccccc2)nc(N)c1C(=N)Nc1ccc(C(F)(F)F)cc1</smiles>

Figure 3. Structure of OBR-5-340<smiles>CN(C)c1ccc(C(=O)O)cc1</smiles>

Figure 4. Structure of 4EDMAB

Lately this group of authors identified novel druggable pocket within a conserved VP1-VP3 interprotomer interface of the enteroviral capsid and developed a new inhibitor targeting this pocket. This molecule (a 4-(1,3-dioxoisoindolin-2-yl) benzenesulphonamide derivative, Fig. 5) has micromolar activity in vitro against a broad range of enteroviruses including CVB3 [2].

\section{Protease inhibitors}

CVB proteases are attractive targets for drug design. $3 \mathrm{C}$ protease is more conserved, than $2 \mathrm{~A}$ protein, therefore most protease inhibitors targets $3 \mathrm{C}$ protease. Rupintrivir (also known as AG7088, Fig. 6) is the earliest direct irreversible protease inhibitor originally developed at Pfizer to inhibit human rhinovirus infection via targeting rhinovirus protease. More importantly, it also has activity against CVB3 in vitro [30]. As mentioned above, 3C specifically cleaves viral polyprotein at the Gln-Gly peptide bond, rupintrivir mimics the protease's recognition substrate ALFQ-X, where $\mathrm{X}$ is an reactive electrophilic ethyl propenoate Michael acceptor. Rupintrivir incorporates P1 lactam moieties instead of an L-glutamine residue. When 


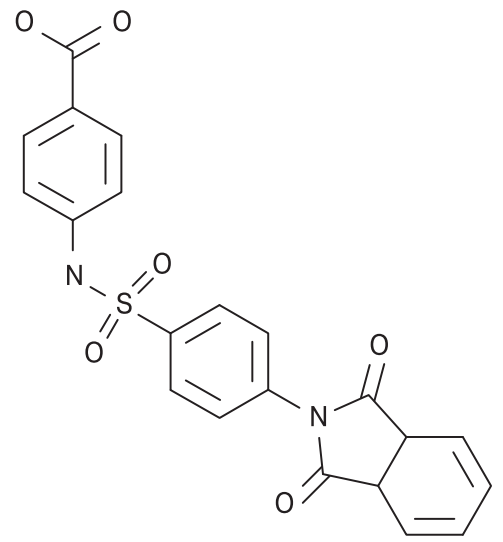

Figure 5. Structure of 4-(1,3-dioxoisoindolin-2-yl) benzenesulphonamide derivative<smiles>CCOC(=O)/C=C/[C@H](C[C@H]1CCNC1=O)NC(=O)[C@H](CC(=O)[C@H](NC(=O)c1cc(C)on1)C(C)C)Cc1ccc(F)cc1</smiles>

Figure 6. Rupintrivir structure

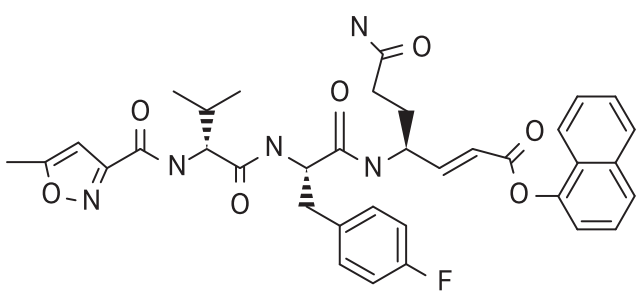

Figure 7. Structure of rupintrivir derivative 3CPI<smiles>Cc1cc(C(=O)N[C@H](C(=O)N[C@@H](Cc2ccc(F)cc2)C(=O)N[C@@H](/C=C/C(=O)OCc2cn3c(C)cccc3n2)CCC(N)=O)C(C)C)no1</smiles>

Figure 8. Structure of rupintrivir derivative LDD1588<smiles>NC(CO)C(=O)NNCc1ccc(O)c(O)c1O</smiles>

Figure 9. Structure of benzerazide bound to the $3 \mathrm{C}$ protease active site, this important moiety reacts with the protease's nucleophilic Cys147 $-\mathrm{SH}$ in the P1' active site via a Michael addition to form an $\mathrm{S}-\mathrm{C}$ covalent bond, irreversibly inhibiting the protease. This peptidomimetic drug candidate reached clinical trials but was halted from further development: it failed in a study of naturally infected patients. Its ethyl moiety is rapidly hydrolyzed to yield an inactive acid form, therefore the need for multiple daily doses to achieve efficacy is the major disadvantage of rupintrivir [3].

According to the reports published, several rupintrivir analogs were designed and tested both in vitro and in vivo. In one study the most promising derivative (3CPI) showing antiviral activity against CVB3 in vitro was the derivative carrying a naphthalene ring (Fig. 7) [44]. This compound was water-insoluble and dissolved only in DMSO. In vivo studies using murine acute myocarditis model induced by CVB3-H3 strain proved that this compound possesses high antiviral activity. Upon delivery via micro-osmotic pumps implanted subcutaneously this peptidomimetic inhibited CVB3 protease activity, significantly inhibited viral proliferation, and reduced myocardial inflammations, fibrosis and mortality in vivo.

The drawback of insolubility of 3CPI was overcame in the next study where solubility of the compound was improved by replacement of naphthalene group with benzimidazole, which gave novel coxsackievirus 3C protease inhibitor LDD1588 (Fig. 8). Its water-soluble $\mathrm{HCl}$-salt form was tested in $\mathrm{mu}-$ rine chronic myocarditis model using the DBA/2 strain. Intraperitoneal administration of $\mathrm{HCl}$ salt form of LDD1588 for 3 days after CVB3 infection had strong antiviral effects manifested in markedly inhibited virus replication, decreased virus titers in various organs, myocardial damage and mortality [24]. Moreover, LDD1588 treatment prevented the progression from post-myocarditic remodeling to dilated cardiomyopathy.

It is worth to note, that though the electrophilic covalent binding between inhibitors (like rupintrivir and its analogues) provide irreversible inhibition, the electrophilic nature of these inhibitors increase the possibility of off-target activity against host cysteine proteases. Recently, it was described, that surprisingly benzerazide (Fig. 9), a commercial drug developed by Roche for management of Parkinson's disease, inhibits CVB3 3C protease in in vitro enzyme assay [18]. In appeared that benzerazide is a noncompetitive protease inhibitor that interacts with a putative allosteric binding site. 2,3,4-trihydroxybenzyl moiety of benzerazide is the most important pharmacophore for enzyme's inhibitory activity.

Benzerazide was further optimized to increase anti CVB3 activity and a series of its derivatives was generated [19]. The most effective in vitro compound was 5-(4-hydroxyphenyl)-N'-(2,3,4-trihydroxybenzyl)pentanehydrazide (Fig. 10A). It shows activity 
against $\mathrm{CV}$ protease in enzyme inhibition assay and then its soluble derivative with valeryl ester group at the 2,3,4-trihydroxy moiety (Fig. 10B) was potent in cell-based assay. Enzyme kinetics studies suggested that this compound is a mixed reversible inhibitor, which combines the characteristics of competitive and non-competitive inhibitors. Thus, the compound could interact with either the enzyme or the enzymesubstrate complex without substrate binding effects and could reacts with $3 \mathrm{C}$ protease to form the inactive complex.

\section{Inhibitors of replication}

Inhibitors of CVB 3D polymerase can be divided into nucleoside/nucleotide inhibitors (NIs) and nonnucleoside/nucleotide inhibitors (NNIs). NI can inhibit viral replication directly via incorporation in nascent nucleic acid inducing lethal mutations and/or indirectly affecting cellular nucleotide pool. In late 1980s it was demonstrated that a widely used synthetic nucleoside ribavirin (Fig. 10), structurally related to inosine and guanosine, effectively inhibited myocardial CVB3 replication and reduced myocardial damage during the acute viral infection [20]. Unfortunately, adverse effects (in particular, hemolytic anemia) limit application of ribavirin.

A cytidine analog, gemcitabine used in cancer treatment has micromolar activity against CVB3 in vitro. This $\mathrm{NI}$ incorporates directly in nascent RNA as a nucleoside analog and potently inhibits ribonucleotide reductase enzyme. Later, it was demonstrated, that inhibition of the pyrimidine biosynthesis upon gemcitabine treatment is associated with upregulation of several IFN stimulated genes, which are the major effectors in the innate immunity [22]. 5-nitrocytidine (Fig. 11) was shown to have antiviral activity against CVB3 superior to ribavirin in vitro, but no results of studies on its potency in vivo have been reported yet though it is used in vitro as an inhibitor of RdRp [15].

Several N-6-substituted analogues of adenosine (JA24, JA25, Fig. 13, A, B) and guanosine (JA28, JA30, Fig. 13, C, D) greatly reduced CVB3 titer in vitro without being efficient substrates for cellular ribonucleotide reductase [12]. The latter suggests that they may not be converted to deoxyribonucleotides, which reduces the chance of genetic damage to replicating cellular DNA. Unfortunately, these NI have not reached animal studies since then maybe due to their cytotoxicity revealed in cell based assay.

Examples of NNI of CVB3 3Dpol with defined mechanism of action are amiloride (Fig. 14A) and GPC-N114 (Fig. 15). Amiloride (a diuretic drug) and its more potent derivative 5-(N-ethyl-N-isopropyl) amiloride (EIPA, Fig. 14B) were shown to inhibit CVB3 RNA replication in cell culture [29]. They compete with incoming nucleoside triphosphates (NTPs) and $\mathrm{Mg}^{2+}$. Amiloride and EIPA inhibit VPg uridylylation and RNA elongation by CVB3 3Dpol
A<smiles>O=C(CCCCc1ccc(O)cc1)NNCc1ccc(O)c(O)c1O</smiles>

B<smiles>CCCCC(=O)Oc1c(O)ccc(CNNC(=O)CCCCc2ccc(O)cc2)c1O</smiles>

Figure 10. Structure of 5-(4-hydroxyphenyl)-N'(2,3,4-trihydroxybenzyl)pentanehydrazide (A) and its soluble derivative (B)<smiles>NC(=O)c1ncn([C@@H]2O[C@H](CO)[C@@H](O)[C@H]2O)n1</smiles>

Figure 11. Structure of ribavirin<smiles>Nc1nc(=O)n([C@@H]2O[C@H](CO)[C@@H](O)[C@H]2O)cc1[N+](=O)[O-]</smiles>

Figure 12. Structure of 5-nitro-cytidine<smiles>NNc1nc(N)nc2c1ncn2[C@@H]1O[C@H](CO)[C@@H](O)[C@H]1O</smiles><smiles>NNc1ncnc2c1ncn2[C@@H]1O[C@H](CO)[C@@H](O)[C@H]1O</smiles>

C<smiles></smiles>

D<smiles>Nc1nc2c(ncn2[C@@H]2O[C@H](C=O)[C@@H](O)[C@H]2O)c(=NO)[nH]1</smiles>

Figure 13. Structure of JA 24 (A), JA25 (B), JA28 (C) and JA30 (D) 
A<smiles>NC(N)=NC(=O)c1nc(Cl)c(N)nc1N</smiles>

B<smiles>CCN(c1nc(N)c(C(=O)N=C(N)N)nc1Cl)C(C)C</smiles>

Figure 14. Amiloride (A) and EIPA (B) structures<smiles>N#Cc1cc([N+](=O)[O-])ccc1Oc1ccc(Cl)cc1Oc1ccc([N+](=O)[O-])cc1C#N</smiles>

Figure 15. Structure of GPC-N114

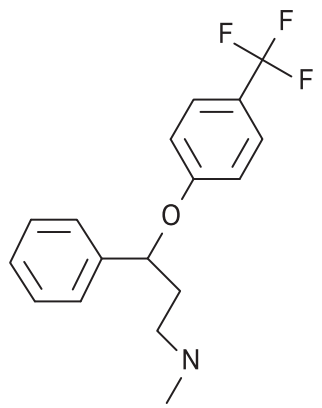

Figure 16. Structure of fluoxetine

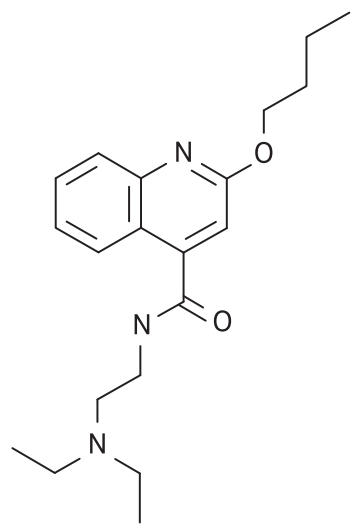

Figure 17. Structure of dibucaine in vitro. Using molecular docking it was suggested, that a binding site for these compounds is located in $3 \mathrm{D}$ protein in close proximity to one of the $\mathrm{Mg}^{2+}$ ions and overlapping the nucleotide binding site.

GPC-N114 [(2,2'-[(4-chloro-1,2-phenylene)bis(oxy)] bis(5-nitro-benzonitrile), Fig. 15] inhibited the elongation activity of recombinant CVB3 polymerase in vitro [41]. Results of study of crystal structure of the inhibitor bound to CVB3 3Dpol proved that GPC-N114 targets the RNA-binding channel of 3Dpol. Interestingly, CVB3 displayed a high genetic barrier to resistance against GPC-N114.

Viral 2C protein represents a very interesting target for antiviral drug design, because it has multiple functions in viral lifecycle and it is highly conserved among enteroviruses. No direct antivirals with distinct chemical structure targeting CVB3 2C protein have been reported yet. Compound KR-22865 inhibited CVB3 replication in vitro via targeting $2 \mathrm{C}$ protein and it taken in pilot animal study in murine model of chronic myocarditis induced by CVB3 infection [23]. Its application reduced virus titers and myocardial damage, maintaining mice heart function. Unfortunately, the authors hide its structural formula, and no new reports on this candidate appeared since then. Several CVB3 in vitro replication inhibitors have been identified from drug repurposing screening: fluoxetine, selective serotonin reuptake inhibitor, dibucaine, local anesthetic, pirlindole, reversible inhibitor of monoamine oxidase type A. Results of resistance mutations study suggested that all these compounds target $2 \mathrm{C}$ protein. For dibucaine (Fig. 16) the direct binding with recombinant $2 \mathrm{C}$ protein in vitro was shown [39]. Fluoxetine (Fig. 17) was demonstrated to reduce 2C ATPase activity in vitro by $50 \%$ in the highest concentration tested [40]. So far, no 2C protein inhibitors have been tested in clinical trials.

\section{Conclusion}

Though most CVB infections can be self-limiting, it is known that CVB3 is one of the major agents for myocarditis. Possibly, the small market for antienteroviral drugs prevents big pharma industry from screening for enterovirus inhibitors and sponsoring expensive clinical trials. Currently the most advanced approach for anti-CVB drug design is the search for new direct antivirals and the modification of existing antiviral compounds. Drug repurposing screening is another approach for antiviral discovery. It is supposed that, in contrast to direct antivirals, drugs targeting host factors offer a higher barrier for viral resistance development of RNA viruses, because cellular targets are unlikely to attain mutations in response to therapy. Nevertheless, it was shown that after 16 weeks of selection CVB3 can develop resistance in vitro to a novel PI4KIII $\beta$ inhibitor by acquiring substitutions in viral $3 \mathrm{~A}$ protein [42]. It is questionable whether resistance will develop in vivo 
upon short-term selection pressure, because often enterovirus infections are acute and of limited duration. Besides, it should be noted that targeting host cell machinery can provoke adverse effects and toxicity. Application of combinational drugs may delay or prevent the emergence of drug-resistant viruses.
Targeted antiviral drug discovery depends on basic knowledge of virus lifecycle and fundamental research on the role of viral enzymes as well as essential host factors for viral replication is necessary for the development of broad-range antiviral drugs against these important pathogens.

\section{References}

1. Романенкова Н.И., Бичурина М.А., Розаева Н.Р., Канаева О.И., Шишко Л.А., Черкасская И.В., Кириллова Л.П. Вирусы Коксаки В1-6 как этиологический фактор энтеровирусной инфекции // Журнал инфектологии. 2016. T. 8, № 2. C. 65-71. [Romanenkova N.I., Bichurina M.A., Rozaeva N.R., Kanaeva O.I., Shishko L.A., Cherkasskaya I.V., Kirillova L.P. Coxsackieviruses B1-6 as etiological factor of enterovirus infection. Zhurnal infektologii = Journal of Infectology, 2016, vol. 8, no. 2, pp. 65-71. (In Russ.)]

2. Abdelnabi R., Geraets J.A., Ma Y., Mirabelli C., Flatt J.W., Domanska A., Delang L., Jochmans D., Kumar T.A., Jayaprakash V., Sinha B.N., Leyssen P., Butcher S.J., Neyts J. A novel druggable interprotomer pocket in the capsid of rhino- and enteroviruses. PLoS Biol., 2019, vol. 17, no. 6: e3000281. doi: 10.1371/journal.pbio.3000281

3. Ang M.J., Lau Q.Y., Ng F.M., Then S.W., Poulsen A., Cheong Y.K., Ngoh Z.X., Tan Y.W., Peng J., Keller T.H., Hill J., Chu J.J., Chia C.S. Peptidomimetic ethyl propenoate covalent inhibitors of the enterovirus 71 3C protease: a P2-P4 study. J. Enzyme Inhib. Med. Chem., 2016, vol. 31, no. 2, pp. 332-339. doi: 10.3109/14756366.2015.1018245

4. Bailey J.M., Tapprich W.E. Structure of the $5^{\prime}$ nontranslated region of the coxsackievirus b3 genome: chemical modification and comparative sequence analysis. J. Virol., 2007, vol. 81, no. 2, pp. 650-668. doi: 10.1128/JVI.01327-06

5. Błyszczuk P. Myocarditis in humans and in experimental animal models. Front. Cardiovasc. Med., 2019, vol. 6: 64. doi: 10.3389/ fcvm.2019.00064

6. Cai Z., Shen L., Ma H., Yang J., Yang D., Chen H., Wei J., Lu Q., Wang D.W., Xiang M., Wang J. Involvement of endoplasmic reticulum stress-mediated C/EBP homologous protein activation in Coxsackievirus B3-induced acute viral myocarditis. Circ. Heart Fail., 2015, vol. 8, no. 4, pp. 809-818. doi: 10.1161/circheartfailure.114.001244

7. Chen J., Ye X., Zhang X.Y., Zhu Z., Zhang X., Xu Z., Ding Z., Zou G., Liu Q., Kong L., Jiang W., Zhu W., Cong Y., Huang Z. Coxsackievirus A10 atomic structure facilitating the discovery of a broad-spectrum inhibitor against human enteroviruses. Cell Discov., 2019, vol. 5, no. 4, 15 p. doi: 10.1038/s41421-018-0073-7

8. Cornell C.T., Kiosses W.B., Harkins S., Whitton J.L. Coxsackievirus B3 proteins directionally complement each other to downregulate surface major histocompatibility complex class I. J. Virol., 2007, vol. 81, no. 13, pp. 6785-6797. doi: 10.1128/JVI.00198-07

9. Coyne C.B., Bergelson J.M. Virus-induced Abl and Fyn kinase signals permit coxsackievirus entry through epithelial tight junctions. Cell, 2006, vol. 124, no. 1, pp. 119-131. doi: 10.1016/j.cell.2005.10.035

10. Dunn J.J., Bradrick S.S., Chapman N.M., Tracy S.M., Romero J.R. The stem loop II within the $5^{\prime}$ nontranslated region of clinical coxsackievirus B3 genomes determines cardiovirulence phenotype in a murine model. J. Infect. Dis., 2003, vol. 187, no. 10, pp. 1552-1561. doi: 10.1086/374877

11. Dutkiewicz M., Swiatkowska A., Ojdowska A., Smolska B., Dymarek-Babś T., Jasińska A., Ciesiołka J. Molecular mechanisms of genome expression of coxsackievirus B3 that belongs to enteroviruses. BioTechnologia, 2012, vol. 93, no. 4, pp. 414-423. doi: 10.5114/bta.2012.46595

12. Graci J.D., Too K., Smidansky E.D., Edathil J.P., Barr E.W., Harki D.A., Galarraga J.E., Bollinger J.M. Jr., Peterson B.R., Loakes D., Brown D.M., Cameron C.E. Lethal mutagenesis of picornaviruses with N-6-modified purine nucleoside analogues. Antimicrob. Agents Chemother., 2008, vol. 52, no. 3, pp. 971-979. doi: 10.1128/AAC.01056-07

13. Groarke J.M., Pevear D.C. Attenuated virulence of pleconaril-resistant coxsackievirus B3 variants. J. Infect. Dis., 1999, vol. 179, no. 6, pp. 1538-1541. doi: 10.1086/314758

14. Gruez A., Selisko B., Roberts M., Bricogne G., Bussetta C., Jabafi I., Coutard B., De Palma A.M., Neyts J., Canard B. The crystal structure of coxsackievirus B3 RNA-dependent RNA polymerase in complex with its protein primer VPg confirms the existence of a second VPg binding site on Picornaviridae polymerases. J. Virol., 2008, vol. 82, no. 19, pp. 9577-9590. doi: 10.1128/ JVI.00631-08

15. Harki D.A., Graci J.D., Galarraga J.E., Chain W.J., Cameron C.E., Peterson B.R. Synthesis and antiviral activity of 5-substituted cytidine analogues: identification of a potent inhibitor of viral RNA-dependent RNA polymerases. J. Med. Chem., 2006, vol. 49, no. 21, pp. 6166-6169. doi: 10.1021/jm060872x

16. Hayden F.G., Herrington D.T., Coats T.L., Kim K., Cooper E.C., Villano S.A., Liu S., Hudson S., Pevear D.C., Collett M., McKinlay M. Efficacy and safety of oral pleconaril for treatment of colds due to picornaviruses in adults: results of 2 double-blind, randomized, placebo-controlled trials. Clin. Infect. Dis., 2003, vol. 36, no. 12, pp. 1523-1532. doi: 10.1086/375069

17. Jagdeo J.M., Dufour A., Klein T., Solis N., Kleifeld O., Kizhakkedathu J., Luo H., Overall C.M., Jan E. N-terminomics TAILS identifies host cell substrates of poliovirus and Coxsackievirus B3 3C proteinases that modulate virus infection. J. Virol., 2018, vol. 92, no. 8: e02211-17. doi: 10.1128/JVI.02211-17

18. Kim B.K., Cho J.H., Jeong P., Lee Y., Lim J.J., Park K.R., Eom S.H., Kim Y.C. Benserazide, the first allosteric inhibitor of Coxsackievirus B3 3C protease. FEBS Lett., 2015, vol. 589, no. 15, pp. 1795-1801. doi: 10.1016/j.febslet.2015.05.027

19. Kim B.K., Ko H., Jeon E.S., Ju E.S., Jeong L.S., Kim Y.C. 2,3,4-Trihydroxybenzyl-hydrazide analogues as novel potent coxsackievirus B3 3C protease inhibitors. Eur. J. Med. Chem., 2016, vol. 120, pp. 202-216. doi: 10.1016/j.ejmech.2016.03.085

20. Kishimoto C., Crumpacker C.S., Abelmann W.H. Ribavirin treatment of murine coxsackievirus B3 myocarditis with analyses of lymphocyte subsets. J. Am. Coll. Cardiol., 1988, vol. 12, no. 5, pp. 1334-1341. doi: 10.1016/0735-1097(88)92618-6 
21. Kwon B.E., Song J.H., Song H.H., Kang J.W., Hwang S.N., Rhee K.J., Shim A., Hong E.H., Kim Y.J., Jeon S.M., Chang S.Y., Kim D.E., Cho S., Ko H.J. Antiviral activity of oroxylin A against Coxsackievirus B3 alleviates virus-induced acute pancreatic damage in mice. PLoS One, 2016, vol. 11, no. 5: e0155784. doi: 10.1371/journal.pone.0155784

22. Lee K., Kim D.E., Jang K.S., Kim S.J., Cho S., Kim C. Gemcitabine, a broad-spectrum antiviral drug, suppresses enterovirus infections through innate immunity induced by the inhibition of pyrimidine biosynthesis and nucleotide depletion. Oncotarget, 2017, vol. 8, no. 70, pp. 115315-115325. doi: 10.18632/oncotarget.23258

23. Lim B.K., Ju E.S., Lee Y.J., Jang S.A., Youn T.J., Jeon E.-S. RNA helicase (2C) inhibitor prevent enteroviral-mediated cardiomyopathy. Eur. Heart J., 2013, vol. 34, pp. 3502. doi: 10.1093/eurheartj/eht309.3502

24. Lim B.K., Yun S.H., Ju E.S., Kim B.K., Lee Y.J., Yoo D.K., Kim Y.C., Jeon E.S. Soluble coxsackievirus B3 3C protease inhibitor prevents cardiomyopathy in an experimental chronic myocarditis murine model. Virus. Res., 2015, vol. 199, 8 p. doi: 10.1016/ j.virusres.2014.11.030

25. Liu Y., Wang C., Mueller S., Paul A.V., Wimmer E., Jiang P. Direct interaction between two viral proteins, the nonstructural protein 2C and the capsid protein VP3, is required for enterovirus morphogenesis. PLoS Pathog., 2010, vol. 6, no. 8: e1001066. doi: 10.1371/journal.ppat.1001066

26. Ma Y., Abdelnabi R., Delang L., Froeyen M., Luyten W., Neyts J., Mirabelli C. New class of early-stage enterovirus inhibitors with a novel mechanism of action. Antiviral Res., 2017, vol. 147, pp. 67-74. doi: 10.1016/j.antiviral.2017.10.004

27. Makarov V.A., Braun H., Richter M., Riabova O.B., Kirchmair J., Kazakova E.S., Seidel N., Wutzler P., Schmidtke M. Pyrazolopyrimidines: potent inhibitors targeting the capsid of Rhino- and Enteroviruses. Chem. Med. Chem., 2015, vol. 10, no. 10, pp. 1629-1634. doi: 10.1002/cmdc.201500304

28. Muckelbauer J.K., Kremer M., Minor I., Diana G., Dutko F.J., Groarke J., Pevear D.C., Rossmann M.G. The structure of coxsackievirus B3 at 3.5 A resolution. Structure, 1995, vol. 3, no. 7, pp. 653-667. doi: 10.1016/S0969-2126(01)00201-5

29. Ogram S.A., Boone C.D., McKenna R., Flanegan J.B. Amiloride inhibits the initiation of coxsackievirus and poliovirus RNA replication by inhibiting VPg uridylylation. Virology, 2014, vol. 464-465, pp. 87-97. doi: 10.1016/j.virol.2014.06.025

30. Patick A.K., Binford S.L., Brothers M.A., Jackson R.L., Ford C.E., Diem M.D., Maldonado F., Dragovich P.S., Zhou R., Prins T.J., Fuhrman S.A., Meador J.W., Zalman L.S., Matthews D.A., Worland S.T. In vitro antiviral activity of AG7088, a potent inhibitor of human rhinovirus 3C protease. Antimicrob. Agents Chemother., 1999, vol. 43, no. 10, pp. 2444-2450. doi: 10.1128/ AAC.43.10.2444

31. Peischard S., Ho H.T., Theiss C., Strutz-Seebohm N., Seebohm G. A kidnapping story: how coxsackievirus B3 and its host cell interact. Cell Physiol. Biochem., 2019, vol. 53, no. 1, pp. 121-140. doi: 10.33594/000000125

32. Pevear D.C., Tull T.M., Seipel M.E., Groarke J.M. Activity of pleconaril against enteroviruses. Antimicrob. Agents Chemother., 1999, vol. 43, no. 9, pp. 2109-2115. doi: 10.1128/AAC.43.9.2109

33. Robinson S.M., Tsueng G., Sin J., Mangale V., Rahawi S., McIntyre L.L., Williams W., Kha N., Cruz C., Hancock B.M., Nguyen D.P., Sayen M.R., Hilton B.J., Doran K.S., Segall A.M., Wolkowicz R., Cornell C.T., Whitton J.L., Gottlieb R.A., Feuer R. Coxsackievirus B exits the host cell in shed microvesicles displaying autophagosomal markers. PLoS Pathog., 2014, vol. 10, no. 4: e1004045. doi: 10.1371/journal.ppat.1004045

34. Schmidtke M., Wutzler P., Zieger R., Riabova O.B., Makarov V.A. New pleconaril and [(biphenyloxy)propyl]isoxazole derivatives with substitutions in the central ring exhibit antiviral activity against pleconaril-resistant coxsackievirus B3. Antiviral Res., 2009, vol. 81, no. 1, pp. 56-63. doi: 10.1016/j.antiviral.2008.09.002

35. Shi. L., Xiong H., He J., Deng H., Li Q., Zhong Q., Hou W., Cheng L., Xiao H., Yang Z. Antiviral activity of arbidol against influenza A virus, respiratory syncytial virus, rhinovirus, coxsackievirus and adenovirus in vitro and in vivo. Arch. Virol., 2007, vol. 152, no. 8, pp. 1447-1455. doi: 10.1007/s00705-007-0974-5

36. Song J.H., Ahn J.H., Kim S.R., Cho S., Hong E.H., Kwon B.E., Kim D.E., Choi M., Choi H.J., Cha Y., Chang S.Y., Ko H.J. Manassantin B shows antiviral activity against coxsackievirus B3 infection by activation of the STING/TBK-1/IRF3 signalling pathway. Sci. Rep., 2019, vol. 9, no. 1: 9413. doi: 10.1038/s41598-019-45868-8

37. Strating J.R., van der Linden L., Albulescu L., Bigay J., Arita M., Delang L., Leyssen P., van der Schaar H.M., Lanke K.H., Thibaut H.J., Ulferts R., Drin G., Schlinck N., Wubbolts R.W., Sever N., Head S.A., Liu J.O., Beachy P.A., De Matteis M.A., Shair M.D., Olkkonen V.M., Neyts J., van Kuppeveld F.J. Itraconazole inhibits enterovirus replication by targeting the oxysterolbinding protein. Cell Rep., 2015, vol. 10, no. 4, pp. 600-615. doi: 10.1016/j.celrep.2014.12.054

38. Thibaut H.J., van der Linden L., Jiang P., Thys B., Canela M.D., Aguado L., Rombaut B., Wimmer E., Paul A., Pérez-Pérez M.J., van Kuppeveld F., Neyts J. Binding of glutathione to enterovirus capsids is essential for virion morphogenesis. PLoS Pathog., 2014, vol. 10, no. 4: e1004039. doi: 10.1371/journal.ppat.1004039

39. Ulferts R., de Boer S.M., van der Linden L., Bauer L., Lyoo H.R., Maté M.J., Lichière J., Canard B., Lelieveld D., Omta W., Egan D., Coutard B., van Kuppeveld F.J. Screening of a library of FDA-approved drugs identifies several enterovirus replication inhibitors that target viral protein 2C. Antimicrob. Agents Chemother., 2016, vol. 60, no. 5, pp. 2627-2638. doi: 10.1128/AAC.02182-15

40. Ulferts R., van der Linden L., Thibaut H.J., Lanke K.H., Leyssen P., Coutard B., De Palma A.M., Canard B., Neyts J., van Kuppeveld F.J. Selective serotonin reuptake inhibitor fluoxetine inhibits replication of Human enteroviruses B and D by targeting viral protein 2C. Antimicrob. Agents Chemother., 2013, vol. 57, no. 4, pp. 1952-1956. doi: 10.1128/AAC.02084-12

41. Van der Linden L., Vives-Adrián L., Selisko B., Ferrer-Orta C., Liu X., Lanke K., Ulferts R., De Palma A.M., Tanchis F., Goris N., Lefebvre D., De Clercq K., Leyssen P., Lacroix C., Pürstinger G., Coutard B., Canard B., Boehr D.D., Arnold J.J., Cameron C.E., Verdaguer N., Neyts J., van Kuppeveld F.J. The RNA template channel of the RNA-dependent RNA polymerase as a target for development of antiviral therapy of multiple genera within a virus family. PLoS Pathog., 2015, vol. 11, no. 3: e1004733. doi: 10.1371/journal.ppat.1004733

42. Van der Schaar H.M., Leyssen P., Thibaut H.J., de Palma A., van der Linden L., Lanke K.H., Lacroix C., Verbeken E., Conrath K., Macleod A.M., Mitchell D.R., Palmer N.J., van de Poël H., Andrews M., Neyts J., van Kuppeveld F.J. A novel, broad-spectrum inhibitor of enterovirus replication that targets host cell factor phosphatidylinositol 4-kinase III $\beta$. Antimicrob. Agents Chemother., 2013, vol. 57, no. 10, pp. 4971-4981. doi: 10.1128/AAC.01175-13 
43. Xia H., Wang P., Wang G.C., Yang J., Sun X., Wu W., Qiu Y., Shu T., Zhao X., Yin L., Qin C.F., Hu Y., Zhou X. Human enterovirus nonstructural protein 2C ATPase functions as both an RNA helicase and ATP-independent RNA chaperone. PLoS Pathog., 2015, vol. 11, no. 7: e1005067. doi: 10.1371/journal.ppat.1005067

44. Yun S.H., Lee W.G., Kim Y.C., Ju E.S., Lim B.K., Choi J.O., Kim D.K., Jeon E.S. Antiviral activity of coxsackievirus B3 3C protease inhibitor in experimental murine myocarditis. J. Infect. Dis., 2012, vol. 205, no. 3, pp. 491-497. doi: 10.1093/infdis/jir745

45. Zautner A.E., Jahn B., Hammerschmidt E., Wutzler P., Schmidtke M. N- and 6-O-sulfated heparan sulfates mediate internalization of coxsackievirus B3 variant PD into CHO-K1 cells. J. Virol., 2006, vol. 80, no. 13, pp. 6629-6636. doi: 10.1128/JVI.01988-05

46. Zhang Y., Cao W., Xie Y.H., Yang Q., Li X.Q., Liu X.X., Wang S.W. The comparison of $\alpha$-bromo-4-chlorocinnamaldehyde and cinnamaldehyde on coxsackie virus B3-induced myocarditis and their mechanisms. Int. Immunopharmacol., 2012, vol. 14, no. 1, pp. 107-113. doi: 10.1016/j.intimp.2012.06.007

\footnotetext{
Авторы:

Волобуева А.А., научный сотрудник лаборатории экспериментальной вирусологии, ФБУН НИИ эпидемиологии и микробиологии имени Пастера, Санкт-Петербург, Россия;

Зарубаев В.В., д.б.н., старший научный сотрудник лаборатории экспериментальной вирусологии, ФБУН НИИ эпидемиологии и микробиологии имени Пастера, СанктПетербург, Россия;

Ланцева К.С., студент, Санкт-Петербургский государственный университет, Санкт-Петербург, Россия.
}

\section{Authors:}

Volobueva A.S., Researcher, Laboratory of Experimental Virology, St. Petersburg Pasteur Institute, St. Petersburg, Russian Federation; Zarubaev V.V., PhD MD (Biology), Senior Researcher, Laboratory of Experimental Virology, St. Petersburg Pasteur Institute, St. Petersburg, Russian Federation;

Lantseva K.S., Student, St. Petersburg State University, St. Petersburg, Russian Federation. 